Original Article

\title{
PREVALENCE OF OBESITY AM ONG HIGH SCHOOL CHILDREN IN DAKSHINA KANNADA AND UDUPI DISTRICTS
}

\author{
Keerthan Kumar M., Prashanth K., Kavya Elizabeth Baby, Kavya Rashmi Rao, Kumarkrishna B., \\ Krishnamurthy Hegde, M rinal Kumar, Manish Shetty, Navya N., Kavya C.P., \\ Sandeep Kumar G. \& Rahul R. \\ Interns, K. S. Hegde M edical Academy, Nitte University, India - 575018
}

Correspondence:

Keerthan Kumar $M$.

Intern, K. S. Hegde Medical Academy, Nitte University, Mangalore - 575 018, India.

E-mail : keerthanupadhya@gmail.com

\begin{abstract}
:
Objective: the aim of this project is to find out the prevalence of overweight and obesity in the high school children in selected schools of M angalore and M anipal and also to study the association of obesity with different factors like Age, Sex, Physical activity etc.

Methods : Cross sectional Study which included 500 participants from 10 selected schools in Udupi and D.K districts. 50 students were included from each school on the basis of 1 in 5 choosing every $3^{\text {rd }}$ student. In schools with lesser attendance all were included. Following which they were explained the details about the study. Then their height and weight were recorded using standard measurements and the data was collected using the questionnaire.

Results : The overall prevalence of obesity and overweight was found to be $2.6 \%$ and $3.0 \%$ respectively. Prevalence was found to be higher in males, those studying in private schools, staying in nuclear family, consuming fried foods-aerated drinks regularly and in those who do not exercise regularly.
\end{abstract}

Conclusion : Childhood obesity is a major public health problem globally because of changes in lifestyle.

Keywords : BMI, exercise, unhealthy food, education, school

\section{Introduction :}

Childhood obesity is one of the most serious public health challenges of the 21 st century ${ }^{1,2}$. The problem is global and is steadily affecting many low- and middle-income countries, particularly in urban settings ${ }^{3,4}$. The prevalence has increased at an alarming rate. Globally in 2010 the number of overweight children under the age of five is estimated to be over 42 million. Close to 35 million of these are living in developing countries. ${ }^{5}$ Overweight and obesity are the fifth leading risk for global deaths. Overweight and obesity are linked to more death compared to malnutrition.The fundamental cause of obesity and overweight is an energy imbalance between calories consumed and calories expended. Globally, there has been an increased intake of energy-dense foods that are high in fat, salt and sugars and a decrease in physical activity due to the increasingly sedentary nature of many forms of work, changing modes of transportation, and increasing urbanization $^{6,7.8}$. Changes in dietary and physical activity patterns are often the result of environmental and societal changes associated with development and lack of supportive policies in sectors such as health, agriculture, transport, urban planning, environment, food processing, distribution, marketing and education ${ }^{9}$.

Childhood obesity is associated with a higher chance of obesity, premature death and disability in adulthood. But in addition to increased future risks, obese children experience breathing difficulties, increased risk of fractures, hypertension, and early markers of cardiovascular disease, insulin resistance and psychological effects ${ }^{10}$.

In India there is paucity of data on the prevalence of childhood obesity which is an emerging health challenge. Therefore we decided to contribute to the data collection by investigating the prevalence of obesity in high school children in various schools in and around Mangalore and $M$ anipal .This will help us in estimating the local prevalence of this condition and will prepare us for the challenge of introducing primary prevention in this area .Habit 
formation occurs mainly during childhood and adolescence .So primary interventions targeting this age group has high possibility of yielding good results. This is the reason why we have targeted this age group of 12 16years.Thus the aim of this project is to find out the prevalence of overweight and obesity in the high school children in selected schools of $M$ angalore and $M$ anipal and also to study the association of obesity with different factors like Age, Sex, Physical activity etc.Materials and Methods

The study duration was for: 2 months (July-August-2011). Personal interviews and observations were doneQuestionnaires were distributed and weight measurement by weighing scale and height by standard methods.

10 schools across different places in the selected area, of which 5 were government schools and 5 were private schools. The sample size was 500 students.

M ale and female students of grades $8^{\text {th }}$ to $10^{\text {th }}$ are included in the study without considering the proportionality of their distribution. We asked 10 schools across the study area for permission allowing us to conduct our study on their students. From the hundreds of schools spread across this large area of study we selected schools for the study according to our convenience. There was no mechanism for randomization in place. Consent forms were signed by the head of the institutions. Once consent was obtained the data was collected from students.

50 students were included from each school on the basis of 1 in 5 choosing every $3^{\text {rd }}$ student, in schools with lesser attendance all were included. Following which they were explained the details about the study. Then their height and weight were recorded using standard measurements and the data was collected using the questionnaire.The data collected was collated using Excel spreadsheets with double checking of errors. The results were assembled in tabular and graphical formats and statistical analysis was dome through chi square

\section{Results:}

We assessed the prevalence of overweight and obesity and associated factors, in urban and rural school children in Mangalore and Udupi districts in a cross sectional study of 500 school children aged $12-15$ years. The prevalence of obesity and overweight was $2.6 \%$ and $3.0 \%$ (table- 1 ). The prevalence of obesity and overweight was found to be higher in males (table-2). Prevalence of Obesity (4.51\%) was found to be higher in children's studying in private schools as compared to government school (1.28\%) but the prevalence of overweight was found to be higher in government school children.(table-3)The percentage of Overweight (3.11\%) and Obesity (4.15\%) is much higher in children's staying in nuclear family than joint family $(1.89 \%$ and $1.42 \%$ )(table-4).The percentage is high in those who don't exercise regularly (3.2\% and $4.51 \%$ ) as compared to those who exercise regularly $(2.31 \%$ and $1.77 \%)$ and in those who exercise for less than $2 \mathrm{hrs}$ in a day $(3.21 \%$ and 3.92\%)(table-5A 5B).

The percentage is much higher in those who consume pastries, fried food regularly $(4.88 \%$ and $4.44 \%)$ as compared to those who don't consume these regularly (0.72 and $1.81 \%$ )(table-6,7).

\section{Discussion :}

Overweight and obesity are defined as abnormal or excessive fat accumulation that may impair health.

$\mathrm{BM}$ I is a simple index of weight for height that is commonly used to classify overweight and obesity in adults. It is defined as person's weight in kilograms divided by square of height in meters. The WHO definition mentions that BM I is greater than or equal to 25 - overweight, BMI greater than or equal to 30 - obesity. Although WHO defines overweight \& obesity as stated above, we have used the definitions for the Indian population, as stated in the NFI (National Foundation of India) Bulletin, Vol 26,No 4.

The definition for Indian population, used for the study was that BM I greater than or equal to 23 - overweight, and BM I greater than or equal to 25 - obesity

Severity of exercise based on duration was labelled MILD: 
TABLES:Gender and age distribution:

\begin{tabular}{|l|l|}
\hline Males & $217(43 \%)$ \\
\hline Females & $283(57 \%)$ \\
\hline Total & $500(100 \%)$ \\
\hline
\end{tabular}

Age distribution:

\begin{tabular}{|l|l|}
\hline 12 & $148(30 \%)$ \\
\hline 13 & $132(26 \%)$ \\
\hline 14 & $160(32 \%)$ \\
\hline 15 & $60(12 \%)$ \\
\hline Total & $500(100 \%)$ \\
\hline
\end{tabular}

TABLE 1. Showing the relationship of age of school children with obesity.

\begin{tabular}{|l|c|c|c|c|c|}
\hline $\begin{array}{l}\text { Age } \\
\text { (yrs) }\end{array}$ & $\begin{array}{c}\text { Under } \\
\text { weight(kg) }\end{array}$ & $\begin{array}{c}\text { Normal } \\
\text { weight(kg) }\end{array}$ & $\begin{array}{c}\text { Over } \\
\text { weight(kg) }\end{array}$ & Obese(Kg) & Total \\
\hline 12 & $51(74.0 \%)$ & $16(23.0 \%)$ & $1(1.5 \%)$ & $1(1.5 \%)$ & 69 \\
\hline 13 & $69(57.0 \%)$ & $47(39.0 \%)$ & $2(1.6 \%)$ & $3(2.4 \%)$ & 121 \\
\hline 14 & $92(59.0 \%)$ & $57(37.0 \%)$ & $2(1.0 \%)$ & $5(3.0 \%)$ & 156 \\
\hline 15 & $72(47.0 \%)$ & $68(44.0 \%)$ & $8(5.0 \%)$ & $6(4.0 \%)$ & 154 \\
\hline Total & $284(56.8 \%)$ & $188(37.6 \%)$ & $13(2.6 \%)$ & $15(3 \%)$ & 500 \\
\hline
\end{tabular}

1.Relationship of age of school children with obesity

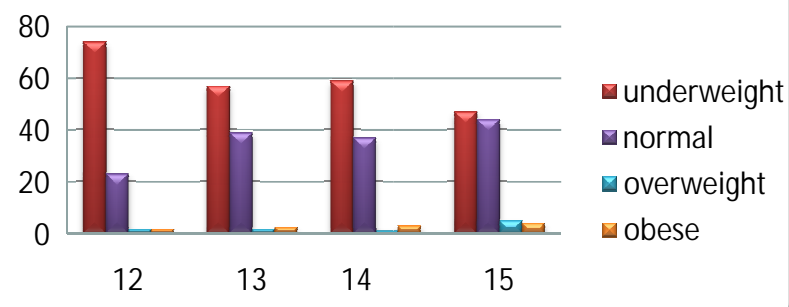

TABLE 2. Showing the relationship of sex of school children with obesity.

\begin{tabular}{|l|c|c|c|c|c|}
\hline Sex & $\begin{array}{c}\text { Under } \\
\text { weight }(\mathrm{kg})\end{array}$ & $\begin{array}{c}\text { Normal } \\
\text { weight }(\mathrm{kg})\end{array}$ & $\begin{array}{c}\text { Over } \\
\text { weight( }(\mathrm{kg})\end{array}$ & $\begin{array}{c}\text { Obese } \\
(\mathrm{kg})\end{array}$ & Total \\
\hline Male & $133(61.0 \%)$ & $71(33.0 \%)$ & $8(3.7 \%)$ & $5(2.3 \%)$ & 217 \\
\hline Female & $151(53.4 \%)$ & $117(41.3 \%)$ & $5(1.8 \%)$ & $10(3.5 \%)$ & 283 \\
\hline Total & $284(56.8 \%)$ & $188(37.6 \%)$ & $13(2.6 \%)$ & $15(3.0 \%)$ & 500 \\
\hline
\end{tabular}

2.Relationship of sex of school children with obesity

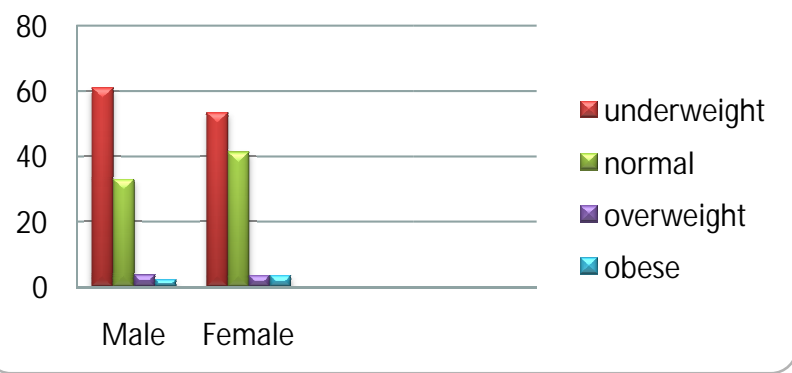

TABLE 3 Showing relationship of type of schools the students are studying in with obesity.

\begin{tabular}{|l|c|c|c|c|c|}
\hline $\begin{array}{l}\text { Type of } \\
\text { School }\end{array}$ & $\begin{array}{c}\text { Under } \\
\text { weight }(\mathrm{kg})\end{array}$ & $\begin{array}{c}\text { Normal } \\
\text { weight(kg) }\end{array}$ & $\begin{array}{c}\text { Over } \\
\text { weight }(\mathrm{kg})\end{array}$ & $\begin{array}{c}\text { Obese } \\
(\mathrm{kg})\end{array}$ & Total \\
\hline Private & $124(47.0 \%)$ & $128(48.0 \%)$ & $2(0.75 \%)$ & $12(4.5 \%)$ & $266(53.2 \%)$ \\
\hline Govt. & $160(68.4 \%)$ & $60(25.6 \%)$ & $11(4.7 \%)$ & $3(1.3 \%)$ & $234(46.8 \%)$ \\
\hline Total & $284(56.8 \%)$ & $188(37.6 \%)$ & $13(2.6 \%)$ & $15(3.0 \%)$ & $500(100 \%)$ \\
\hline
\end{tabular}

3. Relationship of obesity with type of school attended

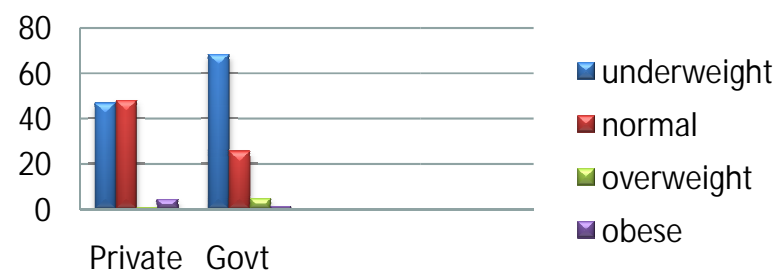

TABLE 4. showing the relationship of type of family the students live in with obesity.

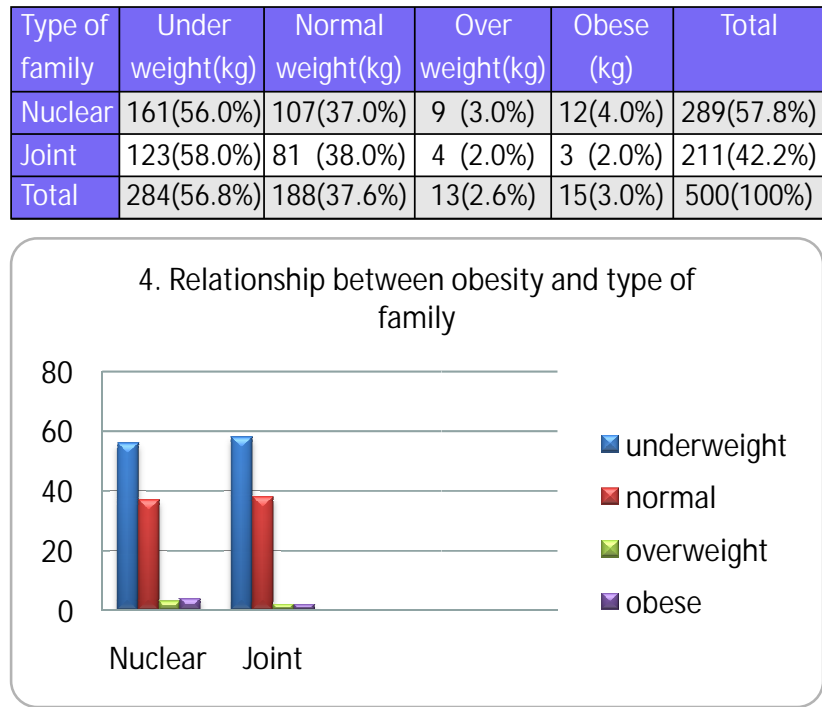

TABLE 5. Showing the relationship between exercise and obesity.

A. Regularity of exercise

\begin{tabular}{|c|c|c|c|c|c|}
\hline & $\begin{array}{c}\text { Under } \\
\text { weight }(\mathrm{kg})\end{array}$ & $\begin{array}{c}\text { Normal } \\
\text { weight }(\mathrm{kg})\end{array}$ & $\begin{array}{c}\text { Over } \\
\text { weight }(\mathrm{kg})\end{array}$ & $\begin{array}{c}\text { Obese } \\
(\mathrm{kg})\end{array}$ & \\
\hline & $150(53.0 \%)$ & $120(43.0 \%)$ & $6(2.0$ & $5(2.0 \%)$ & \\
\hline & 134(61.0\%) & 68 (31.0\%) & $7(3.0 \%)$ & $10(5.0 \%)$ & \\
\hline
\end{tabular}

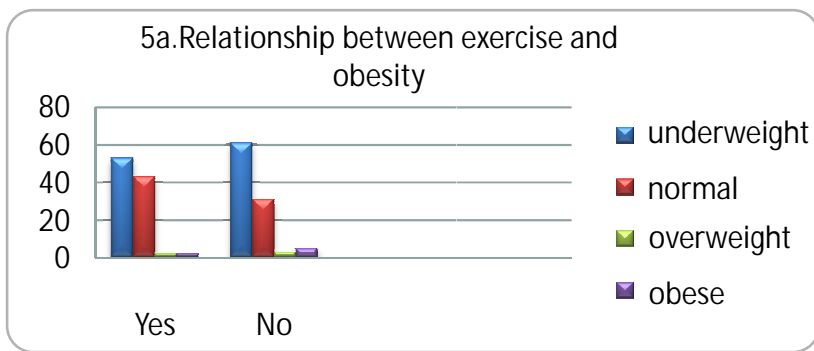


A.Type of exercise

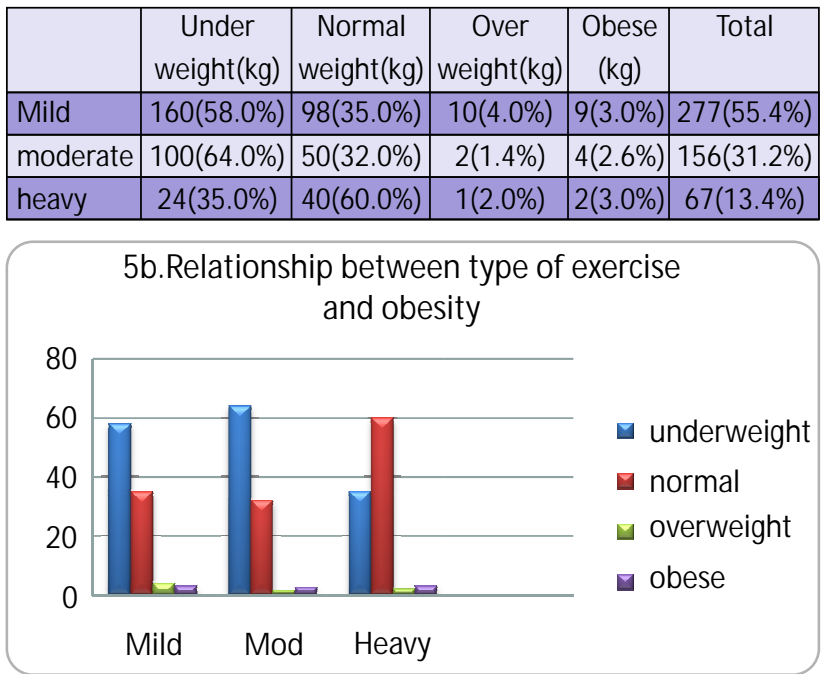

TABLE 6. Showing the relationship of obesity and school children consuming aerated drinks.

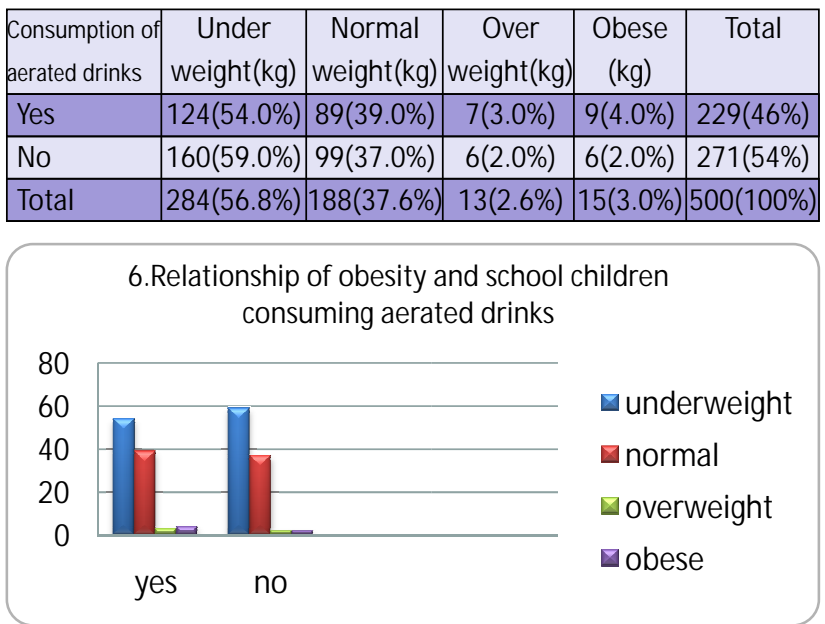

TABLE 7. Showing the relationship between consumption of energy dense food and obesity.

\begin{tabular}{|l|c|c|c|c|c|}
\hline $\begin{array}{l}\text { History of } \\
\text { consumption }\end{array}$ & $\begin{array}{c}\text { Under } \\
\text { weight }(\mathrm{kg})\end{array}$ & $\begin{array}{c}\text { Normal } \\
\text { weight }(\mathrm{kg})\end{array}$ & $\begin{array}{c}\text { Over } \\
\text { weight(kg) }\end{array}$ & $\begin{array}{c}\text { Obese } \\
(\mathrm{kg})\end{array}$ & Total \\
\hline Regular & $104(46.3 \%)$ & $100(44.4 \%)$ & $11(4.9 \%)$ & $10(4.4 \%)$ & $225(45 \%)$ \\
\hline Occasional & $180(65.4 \%)$ & $88(32.0 \%)$ & $2(0.8 \%)$ & $5(1.8 \%)$ & $275(55 \%)$ \\
\hline
\end{tabular}

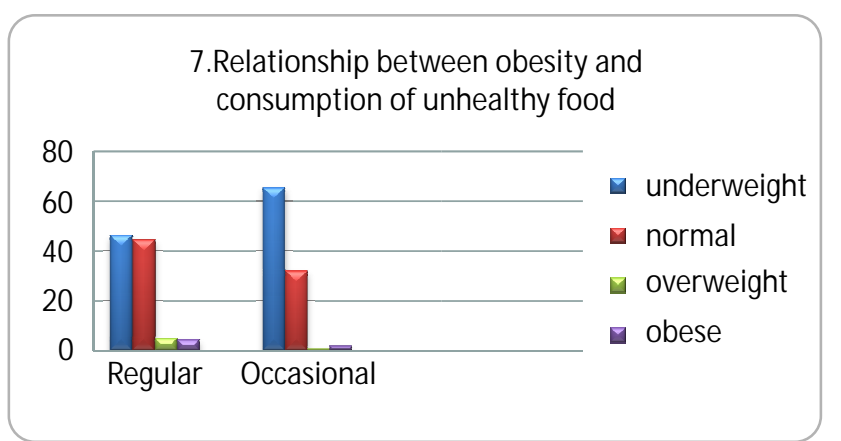

TABLE 8. Showing the relationship between TV viewing (2hrs or more) and obesity.

\begin{tabular}{|l|c|c|c|c|c|}
\hline $\begin{array}{l}\text { TV } \\
\text { Viewing }\end{array}$ & $\begin{array}{c}\text { Under } \\
\text { weight(kg) }\end{array}$ & $\begin{array}{c}\text { Normal } \\
\text { weight(kg) }\end{array}$ & $\begin{array}{c}\text { Over } \\
\text { weight(kg) }\end{array}$ & $\begin{array}{c}\text { Obese } \\
(\mathrm{kg})\end{array}$ & Total \\
\hline Yes & $150(52.0 \%)$ & $120(42.0 \%)$ & $10(3.2 \%)$ & $8(2.8 \%)$ & $288(58 \%)$ \\
\hline No & $134(63.0 \%)$ & $68(32.0 \%)$ & $3(1.0 \%)$ & $7(4.0 \%)$ & $212(42 \%)$ \\
\hline Total & $284(56.8 \%)$ & $188(37.6 \%)$ & $13(2.6 \%)$ & $15(3.0 \%)$ & $500(100 \%)$ \\
\hline
\end{tabular}

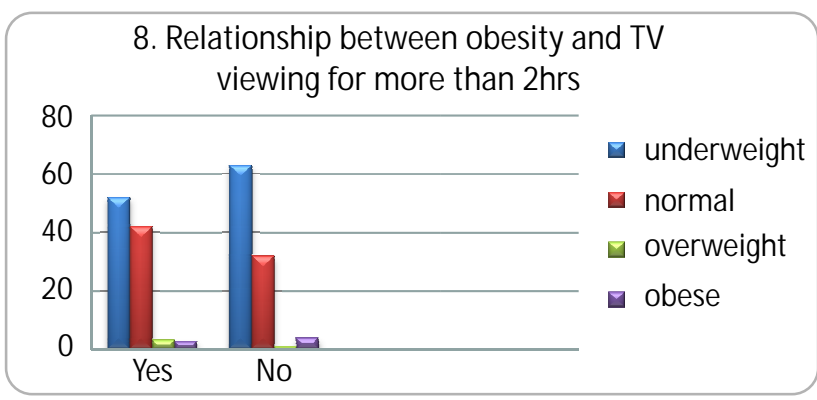

TABLE 9. Showing the relationship of obesity with students getting Tiffin from home.

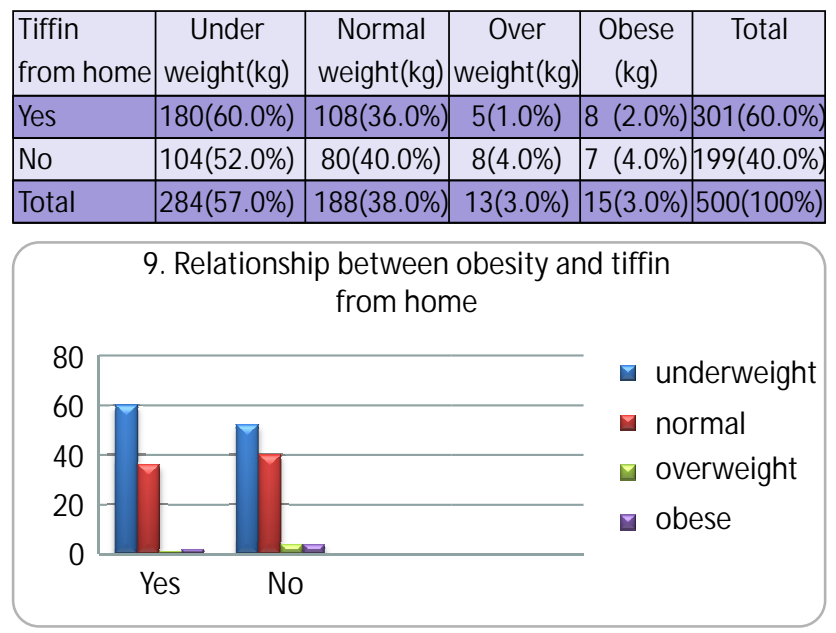

equal to less than 30 minutes. MODERATE: 1 to 2 hours (sweating) HEAVY: more than 3 hours ( $O n$ at least 5 days in a week is taken as regular exercise for this study). For TV viewing, more than $2 \mathrm{hrs}$. per day was taken as regular TV viewing for the purpose of this study. Energy dense food intake was defined as high energy food like energy drinks, fruit juices, pastries, fried food that is rich in sugars and saturated fat. Regular consumption: if consumed more than 4 times a week.

There is a positive co-relation between Age and Obesity. The Prevalence of overweight (5.2\%) and obesity (3.89\%) is highest in 15yr age group and we also found that as age advances there is a significant increase in the prevalence of obesity. (Table 1 Graph 1). 
No significant association was found between sex of school children and obesity; however the overall prevalence of overweight and obesity was found to be higher in females (Tables 2 graph 2).

There is a positive co-relation between Type of school and obesity. The Prevalence of Obesity (4.51\%) was found to be higher in children studying in private schools as compared to government schools $(1.28 \%)$ but the prevalence of overweight was found to be higher in government school children $(4.70 \%)$ as compared to private schools $(0.70 \%)$ (Table 3Graph 3)

No significant association was found between type of family the student's live in with obesity according to $p$ value but the percentage of Overweight (3.11\%) and Obesity $(4.15 \%)$ is much higher in children's staying in nuclear family than joint family(1.89\% and $1.42 \%$ )(table 4 graph 4).Regular physical activity is inversely related to obesity. The percentage is high in those who don't exercise regularly $(3.2 \%$ and $4.51 \%)$ as compared to those who exercise regularly $(2.31 \%$ and $1.77 \%)$ and in those who exercise for less than $2 \mathrm{hrs}$. a day(3.21\% and 3.92\%) (Table $5 a, 5 b$ Graph-5a,5b).

There is a positive co-relationship between overweight and obesity with the consumption of fried foods, energy drinks,

References:

1. Ogden $C L$, Carroll MD, Curtin LR, M CDowell MA et al. "Prevalence of overweight and obesity in the United States, 1999-2004". JAMA (2006 apr5)295(13):154955.

2. Janssen I, Katzmarzyk PT, Boyce WF, Vereecken C et al."Comparison of overweight and obesity prevalence in school-aged youth from 34 countries and their relationships with physical activity and dietary patterns". Obesity Review. (2005 M ay:6(2):123-32

3. Hajian-Tilaki KO,Sajjad P,Razavi A. "Prevalence of overweight and obesity and associated risk factors in urban primary school children in Babol,Islamic Republic of Iran". East M editerranean health journal(2011 Feb.);17(2):109-14.

4. Y Kaneria, P Singh, DC Sharma. "Prevalence of Overweight and Obesity in Relation to Socio-economic Conditions in Two Different Groups of School-age Children of Udaipur City" (Rajasthan). Journal, Indian Academy of Clinical Medicine (April-June, 2006):7(2):133-5.

5. Ramachandran A, Snehalatha C, Vinitha R, Thayyil M et al. "Prevalence of overweight in urban Indian adolescent school children". Diabetes Research and Clinical Practice. (2002 Sep):57(3):185-90.

6. Waker H. "Simple obesity in children. a study on the role of nutritional factors". Med wieku Rozwoj(2006 jan-march);10(1):3-191.

7. Abu Baker NN,Daradkeh SM. "Prevalence of overweight and obesity among adolescents in Irbid governorate,Jordan". East Mediterranean Health journal.(2010jun;16(6):657-62.

8. Hemaideh $\mathrm{SH}, \mathrm{Al}$-Khateeb RY,Al-Rawashdeh AB. "Overweight and obesity and their correlates among Jordanian adolescents". Journal Nurs Scholarsh .2010 Dec;42(4):387-94.

9. Goyal RK,Shah VN,Saboo BD,Phatak SR et al; "Prevalence of overweight and obesity in Indian adolescent school going children:its relationship with socio- pastries and fruit juices regularly as the percentage is much higher in these ( $4.88 \%$ and $4.44 \%$ ) compared to those who don't consume these regularly(0.72 and 1.81\%).(Table 6,7 Graph 6,7).

There is no significant association between obesity and TV viewing ( $>2 \mathrm{hrs}$ ) and children's who get Tiffin from home, however it was found that the prevalence of overweight and obesity is much higher in children who don't get Tiffin from home( $4.02 \%$ and $3.51 \%$ )as compared to those who get Tiffin from home( $1.66 \%$ and 2.65\%).(Table 8, 9 Graph 8 , 9).

\section{Conclusion:}

From the data we have collected we conclude that regular exercise, more than 5 days a week, plays a major role in combating overweight and obesity, and should hence be encouraged. Since TV viewing of more than 2 hrs a day, is a major culprit for childhood obesity, parents and teachers should be advised to engage children in outdoor games and healthy activities. Children carrying tiffin from home, tend to be leaner and hence healthier, as they refrain from eating unhealthy food from out. Hence parents should be advised to take a genuine effort to play a major role in their children's health. Elders-parents and teachers are advised to educate children about the ill effects of aerated drinks and energy dense food.

economic status and associated life style factors"; Journal assoc physicians India.(2010 march);58:151-8.

10. Raj M, Sundaram KR, Paul M, Deepa AS, Kumar RK. "Obesity in Indian children: time trends and relationship with hypertension". Natl Med J India. 2007 NovDec:20(6):288-93

11. Premanath M, Basavanagowdappa H, Shekar MA, Vikram SB, Narayanappa D. "M ysore childhood obesity study". Indian Pediatric journal 2010 Feb:47(2):171-

12. Huffman FG,Kanikireddy S,Patel M. "Parenthood - a contributory factor to childhood obesity". International journal of environmental Research and public health.2010 july,7(7):2800-10.

13. Sharma A, Sharma K, Mathur KP. "Growth pattern and prevalence of obesity in affluent schoolchildren of Delhi". Public Health Nutrition journal.2007 May;10(5):485-91.

14. Gortmaker SL, Must A, Perrin JM, Sobol AM et al. "Social and economic consequences of overweight in adolescence and young adulthood". N Engl J Med. 1993 Sep.

15. Chhatwal J,Verma M , Riar SK. "Obesity among preadolescent and adolescents of a developing country(india)". Asia Pacjournal of clinical nutrition(2004).

16. Kumar S,Raju M,Gowda N. "Influence of parental obesity on school children". Indian journal of pediatrics (2010 march).

17. Lee $A, H o$ MM ,Keung VM: "Global epidemics of childhood obesity is hitting a "less industrialized" corner in Asia:a case study in M acao"; International journal of pediatric obesity(2011 June);6(2-2):e252-6.

18. M ahajan PB,Purty AJ,Singh Z,Cherian J et al; "Study of childhood obesity among school children aged 6-12 years in union territory of puducherry"; Indian journa community medicine.(2011 Jan)36(1):45-50. 